\title{
C-X-C Motif Chemokine 2
}

National Cancer Institute

\section{Source}

National Cancer Institute. C-X-C Motif Chemokine 2. NCI Thesaurus. Code C20474.

C-X-C motif chemokine 2 (107 aa, $11 \mathrm{kDa}$ ) is encoded by the human CXCL2 gene. This protein is involved in the regulation of both chemotaxis and hematopoietic stem cell proliferation. 